Original Paper http://ajol.info/index.php/ijbcs http://indexmedicus.afro.who.int

\title{
Sustainable soil management for improving sorghum [Sorghum bicolor (L.) Moench] production in West Africa, Burkina Faso
}

\author{
Jacques SAWADOGO ${ }^{1 *}$, Pane Jeanne d'Arc COULIBALY ${ }^{1}$, \\ Wendpouiré Carine VALEA ${ }^{2}$ and Jean Boukari LEGMA ${ }^{3}$ \\ ${ }^{I}$ Centre National de la Recherche Scientifique et Technologique/Institut de l'Environnement et de Recherches \\ Agricoles (CNRST/INERA), 01 BP 476 Ouagadougou 01 Burkina Faso. \\ ${ }^{2}$ Institut Polytechnique Privé Shalom (IPS) de Ouagadougou, 11 BP 1435 CMS Ouagadougou 11, \\ Burkina Faso. \\ ${ }^{3}$ Université Saint - Thomas - d'Aquin (USTA), Faculté des Sciences et Technologies, \\ 06 BP 10212 Ouagadougou 06, Burkina Faso. \\ *Corresponding author; E-mail: jacquischimie@gmail.com; Tel: (+226)70662117/(+226)77088989
}

\begin{abstract}
Improved sorghum management practice can provide smallholder farmers with stability in their household nutritional needs and ensure food security. This study was therefore conducted to compare the effect of the single of two organic resources and their combined use with inorganic fertilizer (IN) on soil fertility and sorghum production. It was conducted in the Northern part of Burkina Faso. The treatments consisted of two levels of IN (the normal and the half dose of NPK + urea) and two types of organic resources (simple compost $\mathrm{SC}$ and Piliostigma reticulatum leaves compost $\mathrm{CP}$ ). These treatments were combined to give 6 treatments: T1: control ; T2 : SC ; T3 : CP; T4 : SC + 1/2 dose of IN ; T5 : CP + 1/2 dose of IN ; T6 : normal dose of IN. The experiment was led using a randomized complete block design in three replications. The result revealed a greater improvement of soil $\mathrm{pH}$ and nutrients induced by $\mathrm{CP}$ used alone. However, when combined with IN, it decreased significantly soil nutrients and sorghum yield components and yield. Contrary, the SC in combination with IN gave the highest improvement in yield components and yield of sorghum. The use of IN alone increased sorghum yield components and yield but it contributed to decrease soil $\mathrm{pH}$ and nutrients content. A combined use of inorganic and organic fertilizers could be therefore recommended for maintaining soil fertility and for a sustainable production of sorghum.
\end{abstract}

(C) 2020 International Formulae Group. All rights reserved.

Keywords : Organic and inorganic resources, soil nutrients, sorghum yield.

\section{INTRODUCTION}

Agricultural production is a particularly important component of food security in West Africa. However, the reduction of cultivable land and some other resources have created tremendous constraints in the field, leading to a decrease in food demands (Shah and $\mathrm{Wu}$,
2019). To cope with this challenge, innovative strategies for sustainable crop productivity are needed (OCDE, 2019). According to Roobroeck et al. (2016), the integrated soil fertility management (ISFM) is one of the strategies increasing productivity and profitability for smallholder farming systems. 
It is a set of best practices, preferably used in combination, including the use of appropriate germplasm, the appropriate use of fertilizer and of organic resources, and good agronomic practices (Vanlauwe et al., 2015).

In Burkina Faso, as in many subSaharan countries, ISFM techniques are used to regenerate degraded soils and subsequently maintain soil fertility by making efficient and sustainable the use of available nutrients. These ISFM techniques aim at enabling the use of techniques at little extra cost to the farmer, such as organic fertilizers, crop residues and nitrogen-fixing crops, in combination with seed priming and water harvesting.

For this study, different types of organic fertilizers and their combined used with inorganic fertilizers were incorporated to enhance soil fertility, plant growth and the yield of sorghum. Indeed, several researches especially that of Chauhan et al. (2012) reported that using different types of organic and inorganic fertilizers is one of the best techniques to produce more food with limited space. For them, this technique consequently maintains the soil nutrients level and allows plant to grow and deal with pests, diseases and environmental degradation from inorganic fertilization.

Due to its status as a staple crop, improved sorghum management practice can provide smallholder farmers with stability in their household nutritional needs and ensure food security. Depending to the rate of fertilizers combined, this practice was found to improve sorghum yield by $43-87 \%$ (Tonitto et al., 2016) compared with the control yield. Furthermore, this combination of organic and inorganic fertilizers contributed to increase soil N, P and K content (Mahmood et al., 2017; Jjagwe et al., 2020) and soil pH and C content (Zhao et al., 2020).

In Burkina Faso, in addition to increase crop yields, organic farming (practiced by more than 200 active actors) is part of a wide range of modes that support the environment, its main objective being to optimize the health and productivity of interdependent entities that constitute the life of soils, plants, animals and human beings. This study was therefore conducted to compare the effect of two organic resources on soil fertility and on sorghum production.

\section{MATERIALS AND METHODS}

The experiment was conducted during the rainy season of 2018-2019 at Song-Naba, a village in the Northern part of Burkina Faso. Located at $12^{\circ} 57^{\prime} \mathrm{N}$ and $2^{\circ} 16^{\prime} \mathrm{W}$, it is in the agroecological zone with rainfall between 600 and $900 \mathrm{~mm}$ (Sahel zone). The study was conducted in this area to determine the response of sorghum to two types of organic fertilizers in single use and in combined use with inorganic fertilizers (NPK (14-23-14) + urea $(46 \% \mathrm{~N})$ ).

The treatments consisted of two levels of inorganic fertilizer and two types of organic resources: $50 \mathrm{~kg} \mathrm{ha}^{-1}$ of NPK $+25 \mathrm{~kg} \mathrm{ha}^{-1}$ of urea in combination with $30 \mathrm{t} \mathrm{ha}^{-1}$ of simple compost (made of animals manures and crop residues), $50 \mathrm{~kg} \mathrm{ha}^{-1}$ of NPK $+25 \mathrm{~kg} \mathrm{ha}^{-1}$ of urea in combination with $30 \mathrm{t} \mathrm{ha}^{-1}$ of Piliostigma reticulatum (DC.) leaves compost, $100 \mathrm{~kg} \mathrm{ha}^{-1}$ of NPK $+50 \mathrm{~kg} \mathrm{ha}^{-1}$ of urea in single use, $30 \mathrm{t}$ $\mathrm{ha}^{-1}$ of each type of organic resources and a control. The treatments were combined to give 6 treatments combinations: T1 : control ; T2 : application of simple compost (SC) ; T3 : application of compost from the leaves of $P$. reticulatum; $\mathrm{T} 4$ : application of simple compost $+50 \mathrm{~kg} \mathrm{ha}^{-1}$ of NPK $+25 \mathrm{~kg} \mathrm{ha}^{-1}$ of urea ; T5 : application of $P$. reticulatum leaves compost $+50 \mathrm{~kg} \mathrm{ha}^{-1}$ of NPK $+25 \mathrm{~kg} \mathrm{ha}^{-1}$ of urea ; T6 : $100 \mathrm{~kg} \mathrm{ha}^{-1}$ of NPK + $50 \mathrm{~kg} \mathrm{ha}^{-1}$ of urea (recommended dose). The design used for the experiment was a randomized complete block design (RCBD) in three replications.

For the management of the plots, the experimental area was ploughed at about $20 \mathrm{~cm}$ depth with a donkey-coupled plough and harrowed manually before planting. Basal applications of organic resources were done at a dose of $30 \mathrm{t} \mathrm{ha}^{-1}$ in all treatments, except $\mathrm{T} 1$ and $\mathrm{T} 6$. The doses of inorganic fertilizers to be applied were done in two fractions to each of the three treatments T4, T5 and T6. The dose of NPK was applied in two times that one at sowing and the other one plus the dose of urea 45 days after sowing. 
The data collected for the experiment were the phenology of sorghum crop, panicle weight, total biomass, grain yield, harvest index and thousand grain weight (1000 seed). For sorghum phenology, daily field observations were made from booting period until maturity to estimate sorghum reproductive cycle. The observations consisted of noting the number of booting plants per day, and the number of panicles per day. The period of $50 \%$ flowering and the number of panicles was noted at the maturity. Total biomass, grain yield and harvest index were determined using the following formulas:

$$
\begin{aligned}
& \text { Biomass }\left(\mathrm{kg} \mathrm{ha}^{-1}\right)=\frac{\text { Straw weight }(\mathrm{kg})}{\text { Area }(\mathrm{ha})} \times 10 \\
& \text { Grain yield }\left(\mathrm{kg} \mathrm{ha}^{-1}\right)=\frac{\text { Grain weight }(\mathrm{kg})}{\text { Area }(\mathrm{ha})} \times 10 \\
& \text { Harvest index }=\frac{\text { Grain y ield }}{\text { Straw y ield }}
\end{aligned}
$$

Soil analysis was also done using standard analytical procedures to determine soil $\mathrm{pH}$, soil organic carbon (SOC), total nitrogen $(\mathrm{N})$, total and available phosphorus $(\mathrm{P})$, and total and available potassium (K).

The data were analyzed using XLSTAT version 2014.5.03 software. The means of sorghum yield components and yield were separated using Newman-Keuls test when p. values $\leq 0.05$ and soil chemical properties were interpreted using a correlation analysis. software

The graphics were built using Rstudio

\section{RESULTS}

\section{Effect of organic and inorganic fertilizers on soil chemical properties}

Table 1 showed the effect of organic resources and inorganic fertilizers on soil chemical properties. The result revealed that, $30 \mathrm{t} \mathrm{ha}^{-1}$ of simple compost (T2) and $30 \mathrm{tha}^{-1}$ of Piliostigma reticulatum leaves compost (T3) were significantly $(\mathrm{P}<0.05)$ observed to be better in terms of improving soil $\mathrm{pH}, \mathrm{SOC}, \mathrm{N}$ content, total $\mathrm{P}$, and available $\mathrm{P}$ and $\mathrm{K}$. The results further revealed a significant $(\mathrm{P}<0.05)$ difference between the types of organic resources, with a greater improvement of soil nutrients $(\mathrm{pH}, \mathrm{SOC}$, total $\mathrm{N}, \mathrm{P}$ and $\mathrm{K}$, and available $\mathrm{P}$ and $\mathrm{K}$ ) induced by $P$. reticulatum leaves compost in single use (T3). However, when combined with $50 \mathrm{~kg} \mathrm{ha}^{-1}$ of NPK +25 $\mathrm{kg} \mathrm{ha}{ }^{-1}$ of urea, the treatment with $P$. reticulatum leaves compost (T5) decreased significantly $(\mathrm{P}<0.05)$ all the chemical properties of the soil more than the decrease observed in the simple compost combined with $50 \mathrm{~kg} \mathrm{ha}^{-1}$ of NPK $+25 \mathrm{~kg} \mathrm{ha}^{-1}$ of urea (T4). Furthermore, all the treatments were found to be better than the control and the treatment with $100 \mathrm{~kg} \mathrm{ha}^{-1}$ of NPK $+50 \mathrm{~kg} \mathrm{ha}^{-1}$ of urea (recommended dose) (Table 1). Indeed, the rate of chemical fertilizers used in this study was found to decrease soil $\mathrm{pH}$ and nutrients, as well as the decrease observed in the control treatment. It further indicated that the application of $100 \mathrm{~kg} \mathrm{ha}^{-1}$ of NPK $+50 \mathrm{~kg} \mathrm{ha}^{-1}$ of urea has contributed to the loss of soil organic carbon and the degradation of soil (acidification of soil and decline in soil nutrients content).

\section{Effect of organic and inorganic fertilizers on the yield components and yield of sorghum}

From the beginning of flowering to the end of production (at harvest) of sorghum, the results as presented in Figures 1 and 2 revealed the effect of organic resources and inorganic fertilizers on sorghum production. The result showed that the combined application of $30 \mathrm{t}$ $\mathrm{ha}^{-1}$ of simple compost with $50 \mathrm{~kg} \mathrm{ha}^{-1}$ of NPK $+25 \mathrm{~kg} \mathrm{ha}^{-1}$ of urea $(\mathrm{T} 4)$ significantly $(\mathrm{P}<0.05)$ produced highest panicles number, highest panicle weight, biomass, grain yield and harvest index (Figures 1 and 2). However, the combined incorporation of $30 \mathrm{t} \mathrm{ha}^{-1}$ of $P$. reticulatum leaves compost with $50 \mathrm{~kg} \mathrm{ha}^{-1}$ of $\mathrm{NPK}+25 \mathrm{~kg} \mathrm{ha}^{-1}$ of urea (T5) produced less sorghum yield components and yield compared to the single use of this compost and the other treatments, excepted the control one. In addition, the study indicated that the single use of inorganic fertilizers $\left(100 \mathrm{~kg} \mathrm{ha}^{-1}\right.$ of NPK + $50 \mathrm{~kg} \mathrm{ha}^{-1}$ of urea) increased sorghum yield components and yield more than those of the single use of the organic resources (simple compost and $P$. reticulatum leaves compost).

Moreover, the difference of yields induced by the two composts in combination 
with inorganic fertilizers resulted from the nature of these composts. Indeed, the simple compost combined with inorganic fertilizers contributed to improve the yield of sorghum by 3.5 times more than $P$. reticulatum leaves compost combined with this inorganic fertilizers, which nevertheless decreased sorghum yield components and yield more than the single use of $P$. reticulatum leaves compost.

In Figure 2 also, it is shown the effect of organic resources and inorganic fertilizers on 1000 grain weight of sorghum. The result revealed that the single use of organic resources or the application of these organic resources in combination with $50 \mathrm{~kg} \mathrm{ha}^{-1}$ of $\mathrm{NPK}+25 \mathrm{~kg} \mathrm{ha}^{-1}$ of urea, was observed to have a significantly $(\mathrm{P}<0.05)$ highest 1000 grain weight than other treatments (T6:100 $\mathrm{kg} \mathrm{ha}^{-1}$ of NPK $+50 \mathrm{~kg} \mathrm{ha}^{-1}$ of urea and T1: control). This study therefore proved that, application of organic resources alone or in combination with inorganic fertilizers influenced positively 1000 grain weight of sorghum more than the influence induced by the single use of inorganic fertilizers (NPK + urea).

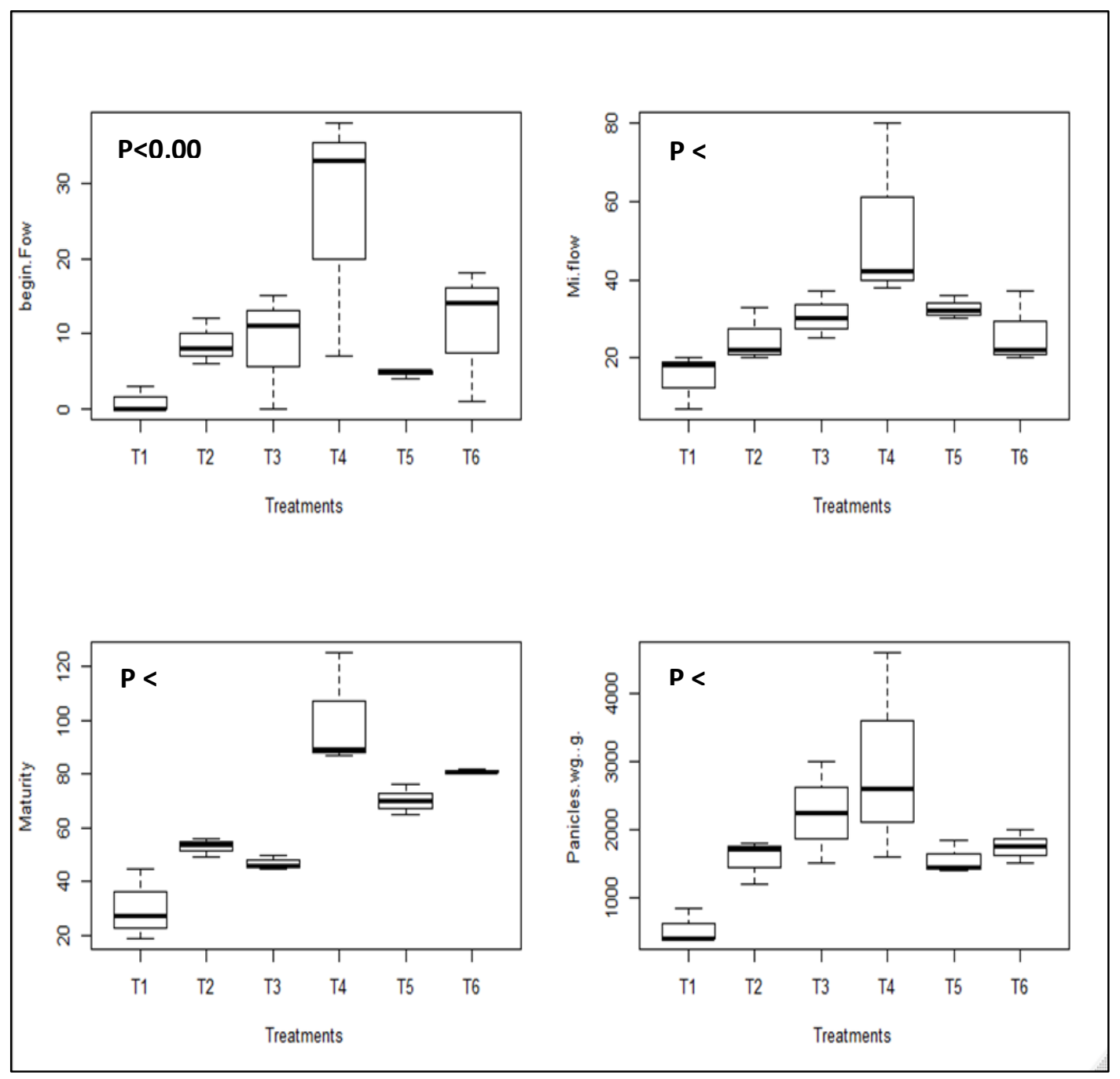

Figure 1: Effect of treatments on the number of panicles at different flowering stages of sorghum Legend: T1 : control ; T2 : Simple Compost (SC) ; T3 : compost from P. reticulatum $(\mathrm{CP}) ; \mathrm{T} 4: \mathrm{T} 2+50 \mathrm{~kg} \mathrm{ha}^{-1}$ of NPK +25 $\mathrm{kg} \mathrm{ha}^{-1}$ of urea $; \mathrm{T} 5: \mathrm{T} 3+50 \mathrm{~kg} \mathrm{ha}^{-1}$ of NPK $+25 \mathrm{~kg} \mathrm{ha}^{-1}$ of urea $; \mathrm{T} 6: 100 \mathrm{~kg} \mathrm{ha}^{-1}$ of NPK $+50 \mathrm{~kg} \mathrm{ha}^{-1}$ of urea ; Begin flow: beginning of flowering; Mi-flow: mi-flowering; Panicles wg: panicles weight. 
Table 1: Correlation among treatments and soil physico-chemical parameters.

\begin{tabular}{|c|c|c|c|c|c|c|c|c|c|c|c|c|c|c|c|}
\hline Variables & T1 & $\mathbf{T 2}$ & $\mathbf{T 3}$ & $\mathbf{T 4}$ & T5 & T6 & $\mathrm{pH}$ & SOC & SOM & $\mathrm{N}$-total & $\mathrm{C} / \mathrm{N}$ & P-total & $\mathrm{P}$ avail & K-total & $\mathrm{K}$ avail \\
\hline $\mathrm{T} 1$ & 1 & & & & & & & & & & & & & & \\
\hline $\mathrm{T} 2$ & $-0,20$ & 1 & & & & & & & & & & & & & \\
\hline $\mathrm{T} 4$ & $-0,20$ & $-0,20$ & $-0,20$ & 1 & & & & & & & & & & & \\
\hline $\mathrm{T} 5$ & $-0,20$ & $-0,20$ & $-0,20$ & $-0,20$ & 1 & & & & & & & & & & \\
\hline SOC & $-0,36$ & 0,40 & 0,48 & 0,04 & $-0,26$ & $-0,29$ & 0,54 & 1 & & & & & & & \\
\hline SOM & $-0,36$ & 0,40 & 0,48 & 0,04 & $-0,26$ & $-0,29$ & 0,54 & 1,00 & 1 & & & & & & \\
\hline N-total & $-0,36$ & 0,44 & 0,44 & 0,00 & $-0,28$ & $-0,24$ & 0,47 & 0,98 & 0,98 & 1 & & & & & \\
\hline $\mathrm{C} / \mathrm{N}$ & $-0,23$ & 0,07 & 0,38 & 0,14 & 0,02 & $-0,38$ & 0,55 & 0,59 & 0,59 & 0,44 & 1 & & & & \\
\hline$K$ avail & $-0,21$ & 0,23 & 0,36 & 0,26 & $-0,26$ & $-0,38$ & 0,66 & 0,60 & 0,60 & 0,55 & 0,45 & 0,63 & $-0,02$ & $\mathbf{0 , 7 8}$ & 1 \\
\hline
\end{tabular}




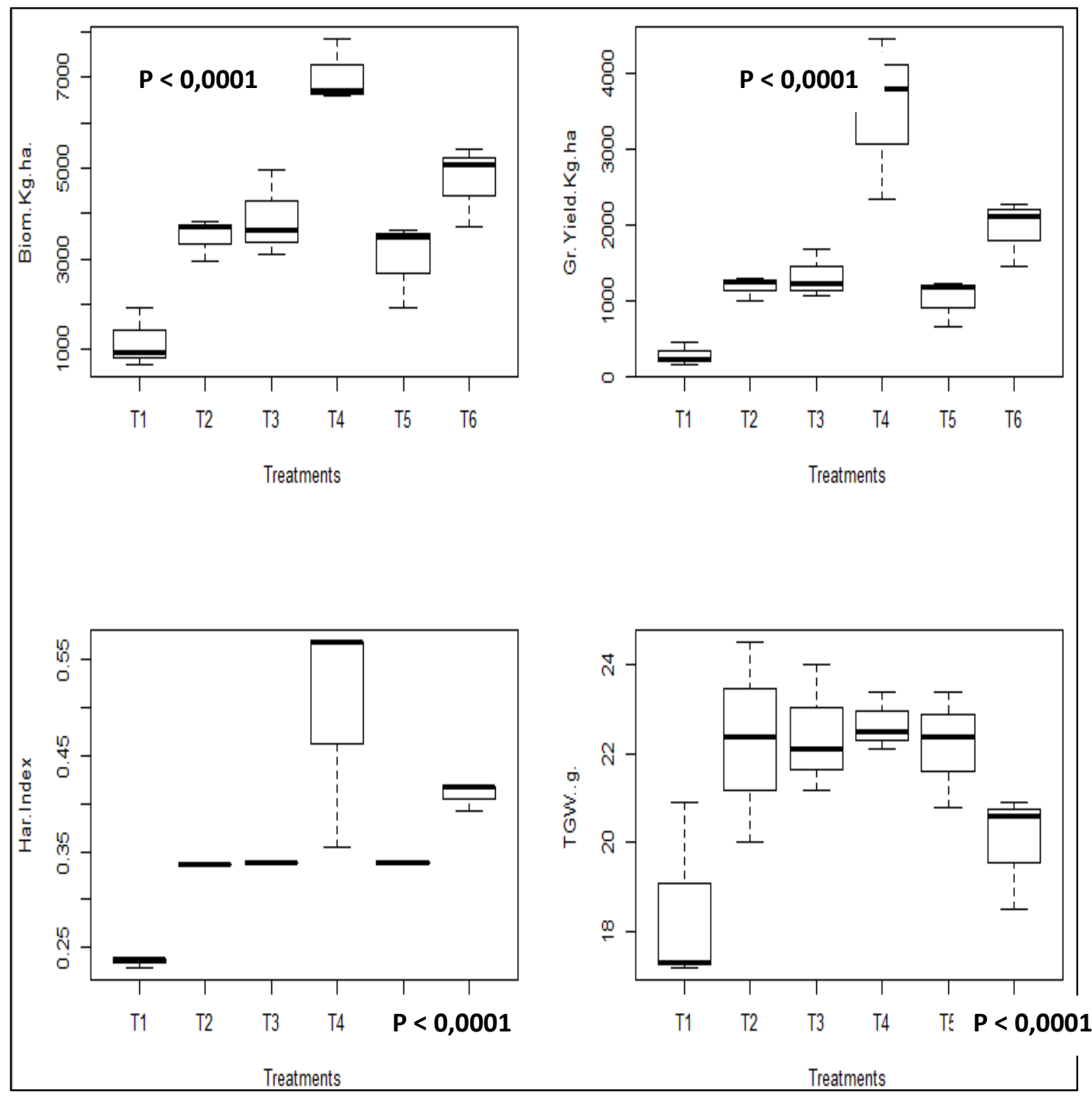

Figure 2 : Effect of treatments on Yield and yield components

Legend : T1 : control ; T2 : Simple Compost (SC) ; T3 : compost from P. reticulatum $(\mathrm{CP}) ; \mathrm{T} 4: \mathrm{T} 2+50 \mathrm{~kg} \mathrm{ha}^{-1}$ of $\mathrm{NPK}+$ $25 \mathrm{~kg} \mathrm{ha}^{-1}$ of urea ; T5 : T3 $+50 \mathrm{~kg} \mathrm{ha}^{-1}$ of NPK $+25 \mathrm{~kg} \mathrm{ha}^{-1}$ of urea ; T6: $100 \mathrm{~kg} \mathrm{ha}^{-1}$ of NPK $+50 \mathrm{~kg} \mathrm{ha}^{-1}$ of urea ; Biom: biomass; Gr yield: grain yield; Har Index: harvest index; TGW: thousand grain weight.

\section{DISCUSSION}

\section{Effect of organic and inorganic fertilizers on soil chemical properties}

The significant difference observed through the study period on soil fertility proved to be better in the compost from $P$. reticulatum leaves compost than the simple compost, indicated that the content of soil nutrients where $P$. reticulatum leaves compost was applied was greater than that found in the soil where the simple compost was applied. Indeed, some chemical analysis showed that $P$. reticulatum leaves compost contains $46,23 \%$ of C, $1.31 \%$ of N, $0.09 \%$ of P, $0.08 \%$ of K with $\mathrm{C} / \mathrm{N}=35 \%$ (Truong et al., 1978) whereas simple compost contains $14,67 \%$ of C, $0,08 \%$ of $\mathrm{N}, 0,08 \%$ of $\mathrm{K}$ with $\mathrm{C} / \mathrm{N}=17 \%$ (Sawadogo et al., 2019). The difference noted between the fertility of the two soils under these two composts could be related to the content of 
nutrients contained in these two composts. Considering the high content of soil nutrients induced by $P$. reticulatum leaves compost, Zounon et al. (2019) asserted that $P$. reticulatum is soil fertility species. However, the significant decrease in soil nutrients content due to the combined incorporation of these two organic resources with NPK + urea in the soil indicated the process of mineralization (for simple compost) and immobilization (for $P$. reticulatum leaves compost). Indeed, the addition of NPK + urea favored the mineralization of carbon in the soil where the simple compost was applied, which enriched the soil with nutrients, favorable for plant growth. Yet, in the presence of NPK + urea, N in the soil where $P$. reticulatum leaves compost was applied was immobilized by soil microorganisms to decompose the organic matter. As this decomposition was not completed, the soil was depleted in $\mathrm{N}$, which has been unfavorable for sorghum nutrition. This result was asserted by those of Dossa et al. (2009), CILSS (2012) and Ba et al. (2014a) who highlighted these processes of mineralization and immobilization of nitrogen. According to Dossa et al. (2009), soils amended with $P$. reticulatum leaf residues immobilized $\mathrm{N}$ during the first 62 days, but later had net release of inorganic $\mathrm{N}$.

This study showed that the rate of chemical fertilizers used contributed to decrease soil $\mathrm{pH}$ and nutrients, as well as the decrease observed in the control treatment. It further indicated that the application of $100 \mathrm{~kg}$ $\mathrm{ha}^{-1}$ of NPK $+50 \mathrm{~kg} \mathrm{ha}^{-1}$ of urea has contributed to the loss of soil organic carbon and its degradation (acidification of soil and decline in soil nutrients content). This is in line with the result of Amonmide et al. (2019), who reported soil chemical properties decline and soil acidification ( $\mathrm{pH}$ was about 5.7-6.5) due to the use of chemical fertilizers in cotton production in Benin. The result also lend its support to the findings of Hati et al. (2008), who showed that adding only $\mathrm{N}$ fertilizers in the soil may result in a deficiency of other nutrients and a decline in soil chemical, biological, and physical properties.

\section{Effect of organic and inorganic fertilizers on} the yield components and yield of sorghum

The current study found that the single use of inorganic fertilizers (100 kg ha-1 of NPK $+50 \mathrm{~kg} \mathrm{ha}^{-1}$ of urea) increased sorghum yield components and yield more than those of the single use of the organic resources (simple compost and $P$. reticulatum leaves compost). This indicates the importance of NPK fertilizer as a basic component of plant physiological activities. The similar results were found by Kouelo et al. (2013) on maize production and by Ahmad et al. (2011) who concluded in their study that to meet the needs of fodder it is better to use inorganic sources that are more effective and quick in response.

The highest panicles number, highest panicle weight, biomass, grain yield and harvest index obtained by the combined application of simple compost with $50 \mathrm{~kg} \mathrm{ha}^{-1}$ of NPK $+25 \mathrm{~kg} \mathrm{ha}^{-1}$ of urea revealed the importance of the combined application of organic resources and inorganic fertilizers in sorghum production. This corroborates the findings of Admas et al. (2015) and Shuaibu et al. (2018) who reported that the incorporation of compost with inorganic fertilizers enhanced grain yield by adding nutrients. The results also confirm that of Anjah et al. (2015) where they reported that combining both compost and NPK would improve on the rapid growth of plants. This finding is also in line with that of Sermé et al. (2015) where the combination of compost with NPK + urea applied increased sorghum yield by $74 \%$ over the control.

Moreover, the difference of yields induced by the two composts in combination with inorganic fertilizers resulted from the nature of these composts. Indeed, the simple compost combined with NPK + urea contributed to improve the yield of sorghum by 3.5 times more than the $P$. reticulatum leaves compost combined with this inorganic fertilizer (NPK + urea) which nevertheless decreased sorghum yield components and yield more than the single use of $P$. reticulatum leaves compost. This result revealed that the NPK fertilizer added to the simple compost favoured $\mathrm{N}$ mineralization, which improved 
soil nutrients content for sorghum plant nutrition. However, the addition of the NPK fertilizer to the $P$. reticulatum leaves compost led to $\mathrm{N}$ immobilization and to a deficiency of soil nutrients content. This agreed with the findings of Dossa et al. (2009) according to whom, Piliostigma reticulatum leaf biomass input into the soil, causes an immobilization of soil nitrogen during the first 62 days. For these authors, leaf residues of $P$. reticulatum input to the soil cannot meet the short-term needs of crops in nitrogen.

Then, this study proved that, application of organic resources alone or in combination with inorganic fertilizers influenced positively 1000 grain weight of sorghum more than the influence induced by the single use of inorganic fertilizers. This supported the finding of Sharif et al. (2006) and Admas et al. (2015), who found significant increase in 1000 grain weight of maize crop induced by the addition of organic fertilizer with NPK fertilizer. This study also lend its support to that of Bayu et al. (2006) whom results revealed significant improvements in the growth and yield of sorghum due to the main and interaction effects of organic resources and inorganic fertilizer application.

\section{Conclusion}

The two organic fertilizers (simple compost and the Piliostigma reticulatum leaves compost) used in this study had different influence on soil $\mathrm{pH}$ and nutrients content. The result revealed a greater improvement of soil $\mathrm{pH}$ and nutrients (SOC, total $\mathrm{N}, \mathrm{P}$ and $\mathrm{K}$, and available $\mathrm{P}$ and $\mathrm{K}$ ) induced by $P$. reticulatum in single use. However, when combined with 50 $\mathrm{kg} \mathrm{ha}^{-1}$ of NPK $+25 \mathrm{~kg} \mathrm{ha}^{-1}$ of urea, the treatment with $P$. reticulatum leaves compost decreased significantly $(\mathrm{P}<0.05)$ the chemical properties of the soil more than the decrease observed in the simple compost combined with $50 \mathrm{~kg} \mathrm{ha}^{-1}$ of NPK $+25 \mathrm{~kg} \mathrm{ha}^{-1}$ of urea. The result further showed less improvement of yield and yield components of sorghum under the use of these organic fertilizers alone compared with their combined use with NPK fertilizer. It was especially observed that the combined application of $30 \mathrm{t} \mathrm{ha}^{-1}$ of simple compost with $50 \mathrm{~kg} \mathrm{ha}^{-1}$ of NPK $+25 \mathrm{~kg} \mathrm{ha}^{-1}$ of urea significantly improved panicles number, panicle weight, biomass, grain yield, harvest index and thousand grain weight. Furthermore, the study indicated that the single use of inorganic fertilizers (100 kg ha-1 of NPK $+50 \mathrm{~kg} \mathrm{ha}^{-1}$ of urea) increased sorghum yield components and yield more than those of the single use of the organic fertilizers (simple compost and $P$. reticulatum leaves compost) but this inorganic fertilizer was seen to decrease soil $\mathrm{pH}$, soil organic carbon and soil nutrients content. Using the inorganic fertilizer alone could not maintain the sustainability of soil fertility. A combined use of this inorganic fertilizer with organic fertilizers could be therefore a better alternative for maintaining soil fertility and for a sustainable production of sorghum.

\section{COMPETING INTERESTS}

The authors declare that they have no competing interests.

\section{AUTHORS' CONTRIBUTIONS}

JS and PJAC designed the research and analyzed the data collected by WCV; PJAC wrote the manuscript corrected by JBL and JS; All authors read and approved the manuscript.

\section{ACKNOWLEDGMENTS}

The authors thank the farmers of SongNaba village for their collaboration and help received during this study. They also express their gratitude to $\mathrm{Mr}$ Sayouba BOUNKOUNGOU, the President of the Association for the Protection of the Environment and Rural Development (APEDR), for having accepted this study in its office and for all the different contributions in the production of composts.

\section{REFERENCES}

Admas H, Gebrekidan H, Bedadi B, Adgo E. 2015. Effects of Organic and Inorganic Fertilizers on Yield and Yield Components of Maize at Wujiraba Watershed, Northwestern Highlands of Ethiopia. Am. J. Plant Nutr. Fert. 
Technol., $\quad \mathbf{5}(1)$ : $1-15 . \quad$ DOI: 10.3923/ajpnft.2015.1.15

Ahmad AH, Wahid A, Khalid F, Fiaz N, Zamir MSI. 2011. Impact of organic and inorganic sources of nitrogen and phosphorus fertilizers on growth, yield and quality of forage Oat (Avena sativa L.). Cercetări Agronomice în Moldova, 3(147): 39-49. DOI: 10.2478/v10298012-0040-7

Amonmide I, Dagbenonbakini G, Agbangba CE, Akponikpe P. 2019. Contribution à l'évaluation du niveau de fertilité des sols dans les systèmes de culture à base du coton au Bénin. Int. J. Biol. Chem. Sci., 13(3): $1846-1860 . \quad$ DOI: 10.4314/ijbcs.v13i3.52

Anjah GM, TABI FO, MVONDO AZE. 2015. Effect of organic and inorganic fertilizers on regeneration of seedlings of Ricinodendron heudelotii (Baill) Pierre et Pax. Int. J. Biol. Chem. Sci., 9(3): 12891298. DOI: $10.4314 /$ ijbcs.v9i3.14

Ba MF, Colinet G, Ndiaye AS, Bassené E. 2014a. Étude de quelques caractéristiques des bois raméaux fragmentés (BRF) de Guiera senegalensis J. F. Gmel et de Piliostigma reticulatum (DC) Hochst et de leur influence sur des propriétés chimiques et biologiques des sols ferrugineux tropicaux du Bassin arachidier, Sénégal. J. Appl. Biosci., 81: 7253 - 7262. DOI: $10.4314 /$ jab.v81i1.5

Bayu W, Rethman NFG, Hammes PS, Alemu G. 2006. Effects of farmyard manure and inorganic fertilizers on sorghum growth, yield, and nitrogen use in a Semi-Arid Area of Ethiopia, J. Plant Nutr., 29(2): 391-407.

DOI: 10.1080/01904160500320962

Chauhan PS, Singh A, Singh RP, Ibrahim MH. 2012. Environmental impacts of organic fertilizers usage in agriculture. In Organic-Fertilizers, Rajeev Pratap Singh (ed). Nova Science Publishers: Inc; 6384.

CILSS. 2012. Bonnes pratiques agro-sylvopastorales d'amélioration durable de la fertilité des sols. Rapport : Burkina Faso.
Dossa EL, Khouma M, Diedhiou I, Sene M, Kizito F, Badiane AN, Samba SAN, Dick RP. 2009. Carbon, nitrogen and phosphorus mineralization potential of semiarid Sahelian soils amended with native shrub residues. Geoderma, $\mathbf{1 4 8}$ (34) : 251-260. DOI: 10.1016/j.geoderma.2008.10.009

Hati KM, Swarup A, Mishra B, Manna MC, Wanjari RH, Mandal KG, Misra AK. 2008. Impact of long-term application of fertilizer, manure and lime under intensive cropping on physical properties and organic carbon content of an Alfisol. Geoderma, 148(2): 173-179. DOI: 10.1016/j.geoderma.2008.09.015

Jjagwe J, Chelimo K, Karungi J, Komakech AJ, Lederer J. 2020. Comparative Performance of Organic Fertilizers in Maize (Zea mays L.) Growth, Yield, and Economic Results. Agronomy, 10(69): 115. DOI: $10.3390 /$ agronomy 10010069

Kouelo FA, Houngnandan P, Gerd D. 2013. Contribution of seven legumes residues incorporated into soil and NP fertilizer to maize yield, nitrogen use efficiency and harvest index in degraded soil in the center of Benin. Int. J. Biol. Chem. Sci., 7(6): $\quad 2468-2489 . \quad$ DOI: 10.4314/ijbcs.v7i6.23

Mahmood F, Khan I, Ashraf U, Shahzad T, Hussain S, Shahid M, Abid M, Ullah S. 2017. Effects of organic and inorganic manures on maize and their residual impact on soil physico-chemical properties. J. Soil Sci. Plant Nutr., 17(1): 22-32. DOI: $\quad 10.4067 / \mathrm{S} 0718-$ 95162017005000002

OCDE. 2019. Innovation, Productivity and Sustainability. in Food and Agriculture: Main Findings from Country Reviews and Policy Lessons, OECD Food and Agricultural Reviews (ed). OCDE; 1-26.

Roobroeck D, Asten PV, Jama B, Harawa R Vanlauwe B. 2016. Integrated Soil Fertility Management: Contributions of Framework and Practices to ClimateSmart Agriculture. Research, 1-9. DOI: 10.13140/RG.2.1.1695.2400 
Sawadogo J, Ouédraogo WBM, Coulibaly PJA, Savadogo CA, Kaboré A, Legma JB. 2019. Étude comparative de la qualité de trois amendements organo-biologiques sur la production de tomate à Soala dans le Centre-Ouest du Burkina Faso.. Sci. Nat. Appl., 38(1) : 35-50.

Sermé I, Ouattara K, Logah V, Taonda JB, Palé S, Quansah C, Abaidoo CR. 2015. Impact of tillage and fertility management options on selected soil physical properties and sorghum yield. Int. J. Biol. Chem. Sci., 9(3): 1154-1170. DOI: 10.4314/ijbcs.v9i3.2

Shah F, Wu W., 2019. Soil and Crop Management Strategies to Ensure Higher Crop Productivity within Sustainable Environments. Sustainability, 11(1485): 1-19. DOI:10.3390/su11051485

Sharif M, Ahmad M, Sarir MS, Khattak RA, NWFP. 2006. Effect of organic and inorganic fertilizers on the yield and yield components of maize. Pak. J. Agric. Sci., 20(1): 11-16.

Shuaibu YM, Abdulmumini BR, Sani K, Zaharaddeen S. 2018. Effect of organic and inorganic fertilizer on the growth and yield of sorghum (Sorghum bicolor (L.) Moench) in Bauchi state, Nigeria. GSCBPS, 02(01): 025-031. DOI: 10.30574/gscbps.2018.2.1.0053.

Tonitto C, Ricker-Gilbert JE. 2016. Nutrient management in African sorghum cropping systems: applying meta-analysis to assess yield and profitability. Agron. Sustain. Dev., 36(10) : 1-19. DOI : 10.1007/s13593-015-0336-8.

Truong B, Pichot JP, Beunard P. 1978. Caractérisation et comparaison des phosphates naturels tricalciques d'Afrique de l'Ouest en vue de de leur utilisation directe leur utilisation directe en Agriculture. L'Agron. Tropic., 33(2) : 136-145.

Vanlauwe B, Descheemaeker K, Giller KE, Huising J, Merckx R, Nziguheba G, Wendt J, Zingore S. 2015. Integrated soil fertility management in sub-Saharan Africa: unravelling local adaptation. SOIL, 1: 491-508. DOI:10.5194/soil-1491-2015

Zhao Z, Zhang C, Li F, Gao S, Zhang J. 2020. Effect of compost and inorganic fertilizer on organic carbon and activities of carbon cycle enzymes in aggregates of an intensively cultivated Vertisol. PLoS ONE, $\quad$ 15(3) :1-16. DOI : 10.1371/journal.pone.0229644

Zounon CSF, Tougiani A, Moussa M, Rabiou H, kiari A, Karimou A. 2019. Diversité et structure des peuplements ligneux issus de la régénération naturelle assistée (RNA) suivant un gradient agroécologique au Centre Sud du Niger. IOSR-JAVS, 12(1): 52-62. DOI: 10.9790/2380-1201035262. 